Acta Theriologica 37 (4): $423-427,1992$.

PL ISSN $0001-7051$

FRAGMENTA THERIOLOGICA

\title{
Some observations on the reproductive biology of collared pika Ochotona rufescens Gray, 1842 from Ziarat Valley, Baluchistan, Pakistan
}

\author{
Mian M. SHAFI, Syed W. A. RIZVI, Amjad PERVEZ, \\ Rajab ALI and Syed Z. SHAH
}

\begin{abstract}
Shafi M. M., Rizvi S. W. A., Pervez A., Ali R. and Shah S. Z. 1992. Some observations on the reproductive biology of collared pika Ochotona rufescens Gray, 1842 from Ziarat Valley, Baluchistan, Pakistan. Acta theriol. 37: 423 - 427.

Some reproductive parameters of collared pika Ochotona rufescens Gray, 1842 were studied during the winter from Ziarat Valley, Baluchistan. Out of 195 animals captured, $105(53.8 \%)$ were males and $90(46.2 \%)$ females. Males were bigger and heavier than non-pregnant females. Mean litter size according to embryo count was $3.6 \pm 1.6$ (range: $1-7$ young/female), and by placental scars $4.48 \pm 0.30$ (range: $2-6$ young/ female). Mean HBL of primiparous females was less than multiparous females. The higher fecundity rate of pika helps to attain its pest status in apple orchards.
\end{abstract}

Vertebrate Pest Control Laboratory, Pakistan Agricultural Research Council, P.O. Box -8401, University Campus, Karachi-75270, Pakistan

Key words: Ochotona rufescens, reproductive biology, Pakistan

\section{Introduction}

The collared pika Ochotona rufescens Gray, 1842 also known as Afghan pika, mouse hare or reddish pika is distributed in Pakistan, Iran, Afghanistan and Uzbekistan (Roberts 1977). In Baluchistan province of Pakistan, the collared pikas are associated with the mountain steppe forest at elevation above $1200 \mathrm{~m}$ and even to $3600 \mathrm{~m}$. It also inhabits the comparatively arid mountain slopes where steppe forests no longer exist, such as in the Chiltan and Bolan (Roberts 1977, Siddiqui 1961).

Pikas are herbivorous lagomorphs which in summer severely damage wheat, corn, potatoes and garden vegetables. During the winter when the natural vegetation is lacking, pikas gnaw/injure the trunks and branches of apple trees, thus reducing the fruit production. Shafi et al. (1989) reported that in 1986 picas damaged an average of $21.6 \%$ (from 14.7 to $25.5 \%$ ) of apple trees, and the yield losses of apples was estimated at 21.2 million rupees in a single crop season. 
Except for some observations (by Roberts 1977, Puget and Gouarderes 1974), no detailed study on the reproductive biology of this species is available. The present paper aims to provide information on litter size, sex ratio and prevalence of pregnancy with reference to head and body length and body weight of pikas.

\section{Materials and methods}

\section{Study area}

The Ziarat district $\left(30^{\circ} 20^{\prime} \mathrm{N}, 67^{\circ} 45^{\prime} \mathrm{E}\right)$ altitude 2,450 meters, is in the north-western sector of Baluchistan province. Precipatations occur mostly in winter months, from December to March, with a variable summer monsoon between June and July. In Ziarat, juniper Juniperus macropoda trees constitute a dry open forest. The soil is extremely rocky and farmers use stones to make fences and terraces which provide good nesting places for pikas. In addition, pikas make burrows under juniper trees and nest in rock slides of the valley.

\section{Data collection}

During the winter of 1986 , pikas were captured in specially designed live traps of $61 \times 17 \times 16$ $\mathrm{cm}$, baited with apple fruit and brought to the laboratory. Individuals were sexed, weighed and measured. All measurements were taken in millimeters. Body weight was obtained by means of a Pesola spring scale with an accuracy of $0.1 \mathrm{~g}$. Reprodutive conditions, i.e. perforation of vaginal orifice, number of visible mammae, lactation, visible pregnancy, number and size of embryos and presence of placental scars were noted in all females.

\section{Results and discussion}

\section{Body size and sex ratio}

From the total of 195 pikas Ochotona rufescens captured, $105(53.8 \%)$ were males and $90(46.2 \%)$ females. Body length and weight distribution in both males and females is presented in Table 1 . Males grew to a greater body weight and

Table 1. Head-body length (HBL) and body weight (Wt) distribution in Ochotona rufescens from Ziarat Valley, Baluchistan as well as differences between sexes.

\begin{tabular}{|c|c|c|c|c|c|}
\hline $\begin{array}{l}\mathrm{HBL} \\
\mathrm{mm}\end{array}$ & $\begin{array}{c}\text { Males } \\
\mathrm{n}\end{array}$ & $\begin{array}{l}\mathrm{Wt} \pm \mathrm{SD} \\
\mathrm{g}\end{array}$ & $\begin{array}{l}\text { Non-pregnant } \\
\text { females, } n\end{array}$ & $\begin{array}{l}\mathrm{Wt} \pm \mathrm{SD} \\
\mathrm{g}\end{array}$ & $p$ \\
\hline $110-130$ & 7 & $79.3 \pm 9.3$ & 5 & $64.0 \pm 5.5$ & $<0.05$ \\
\hline $131-151$ & 10 & $96.3 \pm 18.9$ & 6 & $81.7 \pm 14.7$ & $<0.05$ \\
\hline $152-172$ & 25 & $132.2 \pm 20.3$ & 9 & $118.9 \pm 15.5$ & $<0.05$ \\
\hline $173-193$ & 25 & $160.2 \pm 29.0$ & 8 & $145.0 \pm 14.4$ & $<0.05$ \\
\hline $194-214$ & 18 & $194.4 \pm 31.5$ & 15 & $183.4 \pm 11.0$ & $<0.05$ \\
\hline $215-235$ & 20 & $254.7 \pm 32.2$ & 5 & $235.0 \pm 2.7$ & $<0.05$ \\
\hline Total/Avg. & 105 & $165.9 \pm 59.6$ & 48 & $145.1 \pm 52.5$ & \\
\hline \multicolumn{3}{|c|}{$\begin{array}{l}\text { Maximum Wt of male }=350 \mathrm{~g} \\
\text { Mean } \mathrm{HBL} \pm \mathrm{SD} \text { of male }=181.6 \pm 28.5 \mathrm{~mm}\end{array}$} & \multicolumn{3}{|c|}{$\begin{array}{r}\text { Maximum Wt of female }=240 \mathrm{~g} \\
\pm \mathrm{SD} \text { of female }=177.3 \pm 30.4 \mathrm{~mm}\end{array}$} \\
\hline
\end{tabular}


longer body length than females, the difference in body weight between sexes being significant in all body length classes $(t=2.17 ; \mathrm{df}=151 ; p<0.05)$. According to Markham and Whicker (1973), the average body weight of adult males was bigger than adult females. They also reported that no changes in body weights of both sexes of pikas occur during the winter season. Our data are also in agreement with the above findings. There was a positive relationship between HBL (head and body length) and weight in males $(r=0.89 ; p<0.001)$ and females (non-pregnant; $r=0.95 ; p<0.001$ : pregnant; $r=0.89 ; p<0.001$ ).

Significant difference between the body weight of non-pregnant and pregnant females was observed $(t=14.7 ; \mathrm{df}=88 ; p<0.001)$. The proportion of males to females in the sample was $1: 0.8$. This proportion differs significantly from $1: 1$ sex ratio $\left(\chi^{2}=15.1 ; p<0.01\right)$.

Table 2. Pregnancy, litter size and lactation by head and body length (HBL) of pregnant females.

\begin{tabular}{|c|c|c|c|c|c|c|c|}
\hline $\begin{array}{c}\mathrm{HBL} \\
\mathrm{mm}\end{array}$ & $\begin{array}{c}\text { Females } \\
\mathbf{n}\end{array}$ & $\begin{array}{l}\text { Pregnant } \\
\text { n }\end{array}$ & $\begin{array}{c}\text { t females } \\
\%\end{array}$ & $\begin{array}{c}\text { Litter } \\
\text { size } \\
\bar{x} \pm \mathrm{SD}\end{array}$ & $\begin{array}{c}\text { Lactating } \\
\text { females } \\
\text { n }\end{array}$ & $\begin{array}{l}\text { Lactating } \\
\text { + pregnant } \\
\text { females, } n\end{array}$ & $\begin{array}{c}\text { Reproductively } \\
\text { active females } \\
\%\end{array}$ \\
\hline $131-151$ & 5 & - & - & - & - & - & - \\
\hline $131-151$ & 6 & - & - & - & - & - & - \\
\hline $152-172$ & 11 & 2 & 18.2 & $1.5 \pm 0.70$ & - & 2 & 18.2 \\
\hline $173-193$ & 11 & 3 & 27.3 & $2.0 \pm 1.00$ & 3 & 6 & 54.5 \\
\hline $194-214$ & 28 & 13 & 46.4 & $2.5 \pm 0.77$ & 8 & 21 & 75.0 \\
\hline $215-235$ & 29 & 24 & 82.7 & $4.58 \pm 1.38$ & 5 & 29 & 100.0 \\
\hline Total/Avg. & 90 & 42 & 46.7 & $3.6 \pm 1.6$ & 16 & 58 & 64.4 \\
\hline
\end{tabular}

Mean HBL $\pm \mathrm{SD}=192.7 \pm 29.8 \mathrm{~mm} ;$ Mean Wt $\pm \mathrm{SD}=270.0 \pm 24.9 \mathrm{~g}$; Maximum Wt $=360 \mathrm{~g}$; $50 \%$ pregnant at $215.2 \mathrm{~mm} ; 50 \%$ reproductively active at $212.0 \mathrm{~mm}$.

Table 3. Pregnancy and number of placental scars by head-body length (HBL).

\begin{tabular}{cccccccc}
\hline $\begin{array}{c}\text { HBL } \\
\text { mm }\end{array}$ & $\begin{array}{c}\text { Female } \\
\text { examined } \\
\text { n }\end{array}$ & $\begin{array}{c}\text { Non-pregnant } \\
\text { without } \\
\text { scars }\end{array}$ & $\begin{array}{c}\text { Pregnant } \\
\text { without } \\
\text { scars }\end{array}$ & $\begin{array}{c}\text { Non-pregnant } \\
\text { 1 set } \\
\text { scars }\end{array}$ & $\begin{array}{c}\text { Pregnant } \\
\text { 1 set } \\
\text { scars }\end{array}$ & $\begin{array}{c}\text { Non-pregnant } \\
2 \text { set } \\
\text { scars }\end{array}$ & $\begin{array}{c}\text { Pregnant } \\
\text { s set } \\
\text { scars }\end{array}$ \\
\hline $110-130$ & 5 & 5 & - & - & - & - & - \\
$131-151$ & 6 & 6 & - & - & - & - & - \\
$152-172$ & 11 & 9 & 2 & - & - & - & - \\
$173-193$ & 11 & 5 & 3 & 3 & - & - & - \\
$194-214$ & 28 & 8 & 12 & 7 & 1 & - & - \\
$215-235$ & 29 & - & 15 & 4 & 8 & 1 & 1 \\
Total & 90 & 33 & 32 & 14 & 9 & 1 & 1 \\
\hline
\end{tabular}

At HBL $212.0 \mathrm{~mm} \mathrm{50 \%} \mathrm{were} \mathrm{either} \mathrm{pregnant} \mathrm{or} \mathrm{had} \mathrm{at} \mathrm{least} 1$ set of scars; Mean HBL \pm SD of primiparous females was $205.7 \pm 16.0 \mathrm{~mm}(\mathrm{n}=46)$; Mean $\mathrm{HBL} \pm \mathrm{SD}$ of multiparous females was $219.5 \pm 12.7 \mathrm{~mm}(\mathrm{n}=11)$. 


\section{Litter size}

Mean litter size of $3.6 \pm 1.6$ (range $1-7$ young/female) was recorded from an embryo count in 42 females collected during the winter season (Table 2). The placental scars were observed in 25 females. The mean litter size according to placental scar count was $4.48 \pm 0.3$ (range: $2-6$ young/female). The litter size based on placental scars was greater than estimated from an embryo count which may be due to the fact that litter size in the summer was higher than in the winter (Smith 1974) and 95\% of the litters were born in the summer season. According to Walker (1975), the litter size in $O$. rufescens varied from 2 to 6 young. Mean litter size of 3.6 was recorded by Severaid (1955) by embryo count in captivity. Puget (1973) observed a litter size of 5.5 young/litter, but litter size in pikas varies. First litters were frequently of 3 or 4 young, but later litters may reach 7,8 or 9 and sometimes more. Litter size was observed to be higher with the increase in HBL of females. During the present study higher litter size was also observed with the increase of HBL of the females. However, reproductive fluctuations/ breeding potential of pikas Ochotona princeps in South Western Alberta showed no change in response to environmental parameters in the winter (Millar 1974).

\section{Prevalence of breeding activity}

The prevalence of pregnancy was determined from visible embryos and by placental scars. A summary of the distribution of pregnant or lactating females is shown in Table 2. Out of 90 females autopsied, $42(46.7 \%)$ were visibly pregnant. The first pregnant female was recorded in HBL of $152-172 \mathrm{~mm}$ with mean body weight of $150.0 \mathrm{~g}$. According to Puget (1973), pikas of this class were 5 to 6 weeks old. Puget and Gouarderes (1974) suggest that the smallest pregnant female was not more than 5 weeks old and the largest 8 weeks old. Apparently wild pikas can acquire sexual maturity earlier than captive specimens. In Ziarat, a long breeding season (from ca. 15 March to 30 September) permits $O$. rufescens to produce as many as five litters per female per year (Fulk and Khokhar 1980), which is comparable to $O$. hyperborea and $O$. princeps. In September, an average $64.4 \%$ females were reproductively active, including lactating and pregnant. Reproductivity increases with the increase of HBL class.

Based on the present data, the point at which $50 \%$ of the females were pregnant occurred at HBL of $215.2 \mathrm{~mm}$ and the point at which $50 \%$ of the females were reproductively active (pregnant as well as lactating) occurred at $\mathrm{HBL}$ of $212.0 \mathrm{~mm}$.

Observations on pregnancy and placental scars are presented in Table 3. The point at which $50 \%$ of the females had at least one set of placental scars or were pregnant was at HBL of $212.0 \mathrm{~mm}$. The multiparous females were of greater HBL than primiparous $(t=3.0 ; \mathrm{df}=55 ; p<0.005)$.

During better winter survival, damage to apple trees was recorded to be higher (Khan and Smythe 1980, Shafi et al. 1989). Moreover, the higher fecundity rate of $O$. rufescens apparently enables it to achieve pest status by increase in population density and thereby infesting previously empty areas. 


\section{References}

Fulk G. W. and Khokhar A. R. 1980. Observations on the natural history of a pika (Ochotona rufescens) from Pakistan. Mammalia 44: 51 - 58.

Khan A. A. and Smythe W. R. 1980. The problem of pika control in Baluchistan, Pakistan. In. Proc. Vert. Pest Conf. California (USA) : 130 - 133.

Markham O. D. and Whicker F. W. 1973. Seasonal data on reproduction and body weights of pikas (Ochotona princeps). J. Mammal. 54: 496 - 498.

Millar J. S. 1974. Success of reproduction in pikas Ochotona princeps (Richardson). J. Mammal. 55: $527-542$.

Puget A. 1973. Ochotona rufescens in captivity: reproduction and behaviour. J. Inst. Ani. Tech. 24: $17-24$.

Puget A. and Gouarderes G. 1974. Weight gain of the Afghan pika (Ochotona rufescens) from birth to 19 weeks of age, and during gestation. Growth 38: $117-129$.

Roberts T. J. 1977. The Mammals of Pakistan. Ernest Benn. Limited., London: $1-361$.

Severaid J. H. 1955. The natural history of the pikas (Mammalia, genus Ochotona). Unpublished $\mathrm{Ph} . \mathrm{D}$. thesis, Univ. California, Berkeley: $1-820$.

Shafi M. M., Pervez A. and Ahmed S. M. 1989. Collared pika (Ochotona rufescens) damage to apple orchards in Ziarat Valley, Baluchistan. Pak. J. Agri. Res. 10: 200-203.

Siddiqui M. S. 1961. Checklist of Mammals of Pakistan with particular reference to the Mammalian collection in the British Museum (Natural History) - London. Biologia, Vol. 7 (1 and 2), $93-225$.

Smith A. T. 1974. The distribution and dispersal of pikas: influence of behaviour and climate. Ecology 55: $1368-1376$.

Walker E. P. 1975. Mammals of the World. The Johns Hopkins University Press, Baltimore, London: $1-1500$.

Received 1 June 1992, accepted 10 December 1992. 